\title{
The Function of Legal Research in Formulation of Legislation
}

\author{
Victoria Tabita Majesty Lamada* and Tetania Retno Gumilang \\ Law Faculty of the Tarumanagara University, Jakarta-Indonesia \\ *victoriatabitha31@gmail.com and gumilangteta@gmail.com
}

\begin{tabular}{|l|}
\hline \\
\hline How to cite (in APA style): \\
$\begin{array}{l}\text { Lamada, V. T. M., \& Gumilang, T. R. (2020). The Function of Legal Research in Formulation of Legislation. Jurnal } \\
\text { Hukum Prasada, 7(1), 61-65. https://doi.org/10.22225/jhp.7.1.1373.61-65 }\end{array}$ \\
\hline
\end{tabular}

\section{Abstract}

The formation of legislation is a condition in the framework of national law development which can only be realized if supported by good methods, which are binding on all institutions authorized to make regulations. Indonesia is a state of law that should implement good national legal development, which is carried out in a planned, integrated and sustainable manner in the national legal system. Law No. 12 of 2011 states that research is an important element in the formation of the legislation process. Because it is impossible if a draft legislation is formed before the existence of a legal investigation. This research discussed about the role of legal research in the formation of legislation, as well as what are the benefits of legal research itself. The conclusion is the formation of laws and regulations cannot occur if there is no legal research, because legal research is an internal problem solver in the process of establishing legislation. This legal research itself plays an active role in obtaining valid, correct, rational, and logical data. In addition, legal research is also useful for obtaining raw materials from all aspects, both juridical, socio-psychological, and philosophical that are accurate and complete.

Keyword: Legal research, formulation of legislation.

\section{INTRODUCTION}

Indonesia is a state of law. So that Indonesia has legal rules in the form of legislation. This form of statutory regulation aims to regulate Indonesian society in a better direction. A statutory regulation is impossible to be formed without based on a comprehensive study related to the statutory regulation.

The research referred to above is legal research that carried out to find solutions to legal issues that arise, to provide a prescription of what should be the issue raised. According to Law No. 12/2011 concerning the Formulation of Legislation, research is one of important aspects in formulation of legislation (Indonesia, 2011).

Basically, research is an effort to search for knowledge. This knowledge is used to answer questions from certain ignorance. Because research itself cannot be carried out if it is not preceded by ignorance. With someone's ignorance of something, he will ask, and each question will require an answer. To answer a question, one must know the thing asked. If the answer to the question has not been obtained, then someone who wants to answer it must find an answer (Ali, 2010). According to (Garner \& Black, 2004), legal research is given understanding as:

1. The finding and assembling of authorities that bear on a question of law; and

2. The field of study is concerned with the effective marshaling of authorities that bear on a question of law. 
The legal research itself is carried out to:

1. Finding and collecting authoritative legal material (having authority) regarding certain legal issues; and

2. Fields of study relating to compiling the validity of authoritative legal material (having authority) regarding a particular legal issue. (Black Law Dictionary, $8^{\text {th }}$ ed., 2004).

Legal research is an implementation of MPR Decree No. II/MPR/1993 which states that legal and legal research and development are carried out in an integrated manner, which covers all aspects of life and continues to be improved so that national law can always support and follow the dynamics of development in accordance with the development of community aspirations, as well as current and future needs (Indonesia, 1993).

The utilization of the results of research in the field of law requires cooperation between legal research institutions, universities, and other institutions related to the field of law. Research in the field of law itself is contained in Presidential Decree No. 17 of 1994 concerning Legal Research Activities. The activity was formulated in the national legal system development program (Indonesia, 1994). This program includes the activities of study, legal research, as well as the preparation of academic texts of statutory regulations, both basic and sectoral in addition to development in the field of law in general. Legal studies and research will be conducted on legal issues and social problems, both those that integrate and interact, as well as regional and international legal issues.

The academic manuscript is the initial manuscript that contains ideas, ideas about regulation and material of regulation in certain fields. Therefore, the academic text of the legislation is a text that contains regulatory ideas and legal material that has been reviewed from various aspects of the law that are equipped with a theoretical framework, conceptual framework, principles used as well as an alternative thought about norms which is presented in the form of a systematic description.

Also, other activities include enhancing legal research and development, writing legal scientific papers and organizing legal scientific meetings that present the results of legal studies and research, and the results are outlined in academic texts and regulations. This was intended as the initial activity of the process of revocation, replacement and renewal of colonial legal products also carried out research and study of colonial legal products relating to a particular law that would be replaced and/or renewed. The scientific meeting of the law itself aims to examine a legal issue to continue or cancel a draft law.

\section{METHOD}

The method of approach used in this research is normative-juridical, which is an approach that uses a positivist-juridical conception, namely that law is identical with written norms created by the authorities, so far the law is made as a normative system that is autonomous closed and independent of people's lives.

The research specification used is descriptive-analysis, which is a study that describes the applicable formulation of legislation assembled with positive legal theories concerning the matter being examined. In connection with the method used in this study is the normative-juridical approach, the data source used is secondary data. The secondary data sources referred to include the applicable formulation of legislation, literature books, documents or archives relating to the subject matter written.

The data obtained are then presented in the form of a description arranged systematically, logically, and rationally. In the sense that the overall data obtained will be linked to one another and adjusted to the main points of the problem so that it is a unified whole with the subject matter under study. The data obtained were analyzed in a qualitative normative way which is to describe and interpret the data based on the principles, norms, theories / doctrines of law.

\section{RESULT AND DISCUSSION}

The formation of law is generally known as the formation of laws and regulations. 
(Indonesia, 2011). Implementation of the formation of legislation is usually done by updating existing regulations known as the "renewal dimension" and making completely new regulations known as the "creation dimension" (Aziz, 2012). In the Pre-Legislation Stage the process will be passed:

1. Planning of Draft Law;

2. Preparation of the formulation of a Draft Law consisting of Study, Research and preparation of academic texts;

3. Technical Drafting of Laws consisting of the submission of Initiative Permits to the President, Drafting of Inter-Ministerial Draft Laws, and Socialization of Draft Laws, followed by the finalization of the drafting of Draft Laws; and

4. Formulation of a Draft Law consisting of Technical Drafting of the Draft Law and submission of the President's Mandate to the Chairperson of the People's Representative Council. So, the research and assessment activities are carried out at the pre-legislation stage as a preliminary step before the preparation of the academic text to obtain the raw material for preparing the academic paper referred to, then poured into the draft bill before being submitted to the DPR (Aziz, 2012).

Research is needed in the Pre-Legislative Stage. Because it is impossible if draft legislation is made without being based on a legal study. According to the Big Indonesian Dictionary, research is the activity of collecting, processing, analyzing, and presenting data carried out systematically and objectively to solve a problem or test a hypothesis to develop general principles (Depdikbud, 1988).

In research carried out in engineering and natural sciences are different from research in the social field. Research in the field of engineering and natural sciences does not provide an assessment, but what is pursued is its objectivity because only mathematics and natural sciences are considered to be able to produce objective science. Whereas thought and research in other fields, especially those concerning human mental life, both as individuals (psychology), and in society (such as history, sociology, law, politics and so on) are not possible to produce knowledge or are scientific activities. That is because humans and society change too quickly, making it difficult to conduct experiments repeatedly, which will be able to produce the same research results (Hartono, 1994).

With the help of social sciences, legal research is enriched with the possibility of using methods and techniques commonly used in social sciences research, making it possible to do theological research.

Legal research is a process to obtain data and information about legal norms or methods if something legal material has been regulated in legislation, and legal aspects/ legal needs of the community about something unregulated material then want to be regulated as ius constituendum (BPHN, 1999).

Legal research is a scientific activity that is based on certain methods, systematics, and thinking, which aims to study one or several specific legal phenomena by analyzing them, except that, an in-depth examination of the legal facts is also carried out to later seek a solution to the problems that arise in the symptoms concerned. (Soekanto, 1985).

Legal research is all efforts to find and find the right answers and/or answers that are never wrong about a legal problem. The research will increasingly be needed if more and more problems arise in life. The more complex a life is in line with the increasingly widespread life of the nation and state, and in connection with that, the more problems that arise in the life of the law will also increasingly need research with careful, reliable and valid results to explain and answer the problems that are there is (Wignyosoebroto, 1995).

Legal research consists of 2 (two) groups, namely legal research to answer practical questions, or commonly referred to as legal memorandums, and legal research to answer academic questions. Research to answer academic questions consists of:

1. Normative legal research, which includes:

2. research on legal principles;

3. research on legal principles; 
4. research on legal systematics;

5. research on the degree of legal synchronization;

6. legal history research; and

7. legal comparative research.

8. Empirical legal research which includes:

9. research on legal identification (unwritten law); and

10.research on legal effectiveness (Ali, 2010).

The formation of the legislation process is the process of making Legislation Regulations which basically starts from the planning, preparation, preparation, formulation, discussion, ratification, enactment, and dissemination stages. The legislation is a written regulation that is formed by a state institution or an authorized official and is generally binding (Soeprapto, 2007). In addition, (Krems, 1970) said that the formation of legislation involves: 1) contents of regulations; 2) form and composition of regulations; 3 ) the method of forming regulations; and 4) procedures and processes for establishing regulations.

The effective establishment and functioning of the national legal system are the ultimate goal of national development. The national legal system itself includes legal material, legal apparatus, legal facilities and infrastructure, legal culture, and legal philosophy. Achieving this goal is a "challenge" for all legal apparatuses (police, prosecutors, judges, and lawyers, etc.) to show the best "work" by the position, role, and function possessed by each party.

Research is an important element in the process of forming legislation because research can objectively reveal internal problems in the process of forming legislation. Disclosure of legal issues is useful as a material for consideration and testing of legal principles that will serve as legal principles for the formulation of legislation that are formed.

Such scientific research has a role in obtaining valid and correct data and information and its value are more rational and logical. The information generated in research will help legislators to take and determine rational and logical formulations. This is what distinguishes draft legislation that is only based on intuition or hunch. In addition, you need to know that draft legislation must be preceded by academic research that emphasizes the benefits of making legislation. Therefore, legal research is designed and carried out as an inseparable part of other functions in the process of forming legislation.

The process, in this case, is interpreted as a unified whole, rounded and systemically comprehensive. The systemic relationship between research and the making of legislation is based on the unfolding of research results as the basis for making formulation of legislations. The systemic relationship aims to enrich the alternatives to be made in making laws that are better and more effective in a long time and can function as a means of development and a unifying vehicle for the nation.

Research that has an emphasis on its goals and uses can include a variety of studies. In this case, if the research is seen in terms of its purpose, the research is divided into research to find facts (fact-finding). This kind of research can be continued to find the problem (problem finding), then this research develops into problem identification research and finally, research is conducted to overcome the problem (problem-solution). Another case is that applied research which is oriented towards solving problems in the formulation of legislations (wetgeving swetenschap), which has the object of study regarding how to formulate or form a legal union or regulate human and community life for a time to be banned within a certain period. This seems to require an effort so that the regulation can regulate human events or behavior, which may occur in the future and wherever possible the rules apply as long as possible.

The above description shows that research into problem-solving in the process of establishing statutory regulation is not related to how to solve concrete individual conflicts by applying the norms. However, it examines how to regulate human life so that their interests are protected by realizing legal certainty and the balance of order in society through laws that have been formed based on the procedure of its formation so that it can 
achieve the goal of forming legislation.

However, sometimes problems are found in making formulation of legislations. Problem is, marked by the difficulty of law enforcement in Indonesia, which began since the legislation was made. There are at least two reasons to support this statement. First, legislators do not pay enough attention to whether or not the rules made can be carried out later. The legislators are aware of whether or not they have taken the assumption that the rules are made, will automatically be able to run. At the national level, for example, laws are made without regard to gaps in implementing laws between one region and another. Laws are often made by referring to the conditions of law enforcement in Jakarta or big cities. As a consequence, this law cannot be enforced in most regions in Indonesia and even becomes a death law. The situation is made worse because in making formulation of legislation, it does not pay attention to the different legal infrastructure in various parts of Indonesia. Though the legal infrastructure in law enforcement is very important. Without adequate infrastructure, legislation can't be enforced as expected by legislators (Ali, 2010).

Second, the formulation of legislation is often made unrealistically. This happens to the making of the formulation of legislations which are orders from political elites, foreign countries, and international financial institutions. Here the legislation is considered a commodity. Political elites can determine that statutory regulation is made not because of the needs of the community, but rather that Indonesia has legislation that is comparable (comparable) with industrialized countries. While foreign countries or international legal institutions can ask Indonesia to make certain formulation of legislations as a condition for Indonesia to get foreign loans or grants (Ali, 2010). The two reasons above indicate the legislation since its inception without any strong desire to be upheld because it only has symbolic meaning.

\section{CONCLUSION}

The formation of laws and regulations cannot occur if there is no legal research, because legal research is an internal problem solver in the process of establishing legislation. This legal research itself plays an active role in obtaining valid, correct, rational, and logical data. In addition, legal research is also useful for obtaining raw materials from all aspects, both juridical, socio-psychological, and philosophical that are accurate and complete. From these materials the academic manuscript is then formed which is then poured in the form of articles in a draft law.

\section{REFERENCES}

Ali, H. Z. (2010). Metode Penelitian Hukum. Jakarta: Sinar Grafika.

Aziz, N. M. (2012). Urgensi Penelitian dan Pengkajian dalam Pembentukan Peraturan PerundangUndangan. Jurnal Rechts Vinding, 1(1), 3-8. Retrieved from https://rechtsvinding.bphn.go.id/ ejournal/index.php/jrv/article/view/104/91

BPHN. (1999). Pengkajian Hukum tentang Kedudukan dan Peranan Penelitian Hukum dalam Proses Pembentukan Peraturan Perundang-Undangan.

Depdikbud. (1988). Kamus Besar Bahasa Indonesia (1st ed.). Jakarta: Departemen Pendidikan dan Kebudayaan : Balai Pustaka.

Garner, B. A., \& Black, H. C. (2004). Black's Law Dictionary. USA: St. Paul: Thomson/West.

Hartono, C. F. G. S. (1994). Penelitian Hukum di Indonesia Pada Akhir Abad ke-20. Bandung: Alumni.

Krems, B. (1970). Grundfragen der Gesetzgebungslehre. Berlin: Duncker \& Humblot.

Ketetapan MPR No. 2 Tahun 1993 tentang Garis-Garis Besar Haluan Negara.

Soeprapto, M. F. I. (2007). IImu Perundang-Undangan 1. Yogyakarta: PT Kanisius.

Undang-Undang No. 12 Tahun 2011 tentang Pembentukan Peraturan Perundang-Undangan

Wignyosoebroto, S. (1995). Sebuah Pengantar ke Arah Perbincangan tentang Pembinaan Penelitian Hukum PJP II. In Seminar Akbar 50 Tahun Pembinaan Hukum sebagai Modal bagi Pembangunan Hukum. 